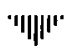

\section{ESCHER: \\ A MATHEMATICIAN IN SPITE OF HIMSELF}

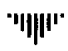

\section{ESCHER : MATHÉMATICIEN MALGRÉ LUI}

\section{Doris Schattschneider \\ Department of Mathematics \\ Moravian College}

Bethlehem, PA 18018

USA

French translation:

Traduction française:

Jean-Luc Raymond

\section{ABSTRACT}

A picture is worth a thousand words... and so the graphic work of the Dutch artist, M.C. Escher (1898-1972), has been captured by mathematicians for its clever visual expression of abstract concepts. However, Escher's finished graphics show only a fraction of his mathematical ability. Escher hotly denied understanding any mathematics, although he acknowledged more affinity with mathematicians than other artists.

No doubt his idea of mathematics was manipulating symbols and creating formulas, or producing or deciphering "hocus pocus" texts. However, Escher was a mathematician, a true researcher, exploring many mathematical questions arising from colored tilings of the plane. He created for himself a set of categories, invented a notation of classification, and ignoring the "accepted" system and restrictions imposed by mathematicians and crystallographers, explored more deeply than any of these 'professionals', questions of colored periodic tilings of the plane. His notebooks of 1941-1942 reveal the extent of the explorations of this closet mathematician. $\stackrel{+}{\div}$

\section{RÉSUMÉ}

Une image vaut mille mots... c'est ainsi que l'oeuvre graphique de l'artiste hollandais M.C. Escher (1898-1972) a gag né l'intérêt des mathématiciens par son expression visuelle éclairée de concepts abstraits. Toutefois, seulement une fraction de l'habileté mathématique d'Escher transparaît dans son oeuvre achevée. Escher niait violemment toute compréhension des mathématiques, malgré le fait qu'il reconnaissait avoir plus d'affinités avec les mathématiciens qu'avec les autres artistes.

Sans doute que son idée des mathématiques en était une de manipulation de symboles et de création de formu les, ou de production ou de déchiffrement de textes abracadabrants. Toutefois, Escher était un mathématicien, un véritable chercheur, qui explora plusieurs questions mathématiques liées aux pavages coloriés du plan. II se créa lui-même un ensemble de catégories, il inventa une notation de classification et, tout en faisant fi du système et des restrictions "reconnus" et imposés par les mathématiciens et les cristallographes, il explora plus en profondeur que tous ces "professionnels» les questions soulevées par les pavag es périodiques du plan. Ses cahiers de notes de 1941-1942 révèlent l'ampleur des recherches de ce mathématicien d'arrière-boutique. 
The graphic work of the Dutch artist M.C. Escher has always held a fascination for mathematicians. At a glance, it is evident that Escher used mathematics in the creation of many works. (Indeed, a more careful look at his preliminary sketches shows his painstaking attention to mathematically determined detail.) Far more striking is Escher's success in creating visual realizations of many difficult-to-explain abstract mathematical concepts: duality, recursion (self-reference), infinity, topological change, dimension.

Escher's notes reveal that he studied mathematical papers on plane tilings by G. Pólya and F. Haag, and used M. Brückner's classic work Vielecke und Vielfläche as a reference. He also corresponded with G. Pólya, H.S.M. Coxeter, R. Penrose, and other mathematicians and scientists. In a lecture in 1953 he admitted, "... I have often felt closer to people who work scientifically (though I certainly do not do so myself) than to my fellow artists." $[1, p .71]$ Despite his frequent and vigorous denials of having any mathematical understanding or of "working scientifically', Escher did possess a deep mathematical curiosity, tenacity, and, ultimately, understanding of a large body of mathematica knowledge. One of the subjects of Escher's research is today called "color symmetry". Only recently, more than forty years after his inquiries, has the field begun to receive serious attention from mathematicians and other scientists.

Escher was a secret mathematician. He had no formal mathematical credentials, and, in fact, seemed as mystified as any layman by the "hocus pocus text" of mathematicians' explanations. But his self-professed mania for producing interlocking creature-shaped tiles to fill the plane led him to systematically explore the possibilities and constraints of such tiles and tilings, as well as the related question of coloring them. He alludes to this in a paragraph from his book Regelmatige vlakverdeling (Regular Division of the Plane) published in 1958:
L'oeuvre graphique de l'artiste hollandais M.C. Escher a toujours entretenu une fascination chez les mathématiciens. D'un coup d'oeil, il est évident qu'Escher a utilisé les mathématiques dans la création de plusieurs de ses travaux. (En effet, un regard plus attentif à ses esquisses préliminaires montre l'attention appliquée qu'il portait aux détails à caractère mathématique.) Encore plus frappant est le succès d'Escher pour ses réalisations visuelles de concepts mathématiques abstraits difficiles à expliquer: dualité, récursion (auto-référence), infini, transformation topologique, dimension.

Les notes d'Escher révèlent qu'il étudia des textes mathématiques de G. Pólya et F. Haag concernant les pavages du plan, et il utilisa l'oeuvre classique de M. Brückner, Vielecke und Vielfläche, à titre de référence. Il correspondit aussi avec G. Pólya, H.S.M. Coxeter, R. Penrose ainsi qu'avec d'autres mathématiciens et scientifiques. Dans une conférence de 1953, il admit, "... Je me sens souvent plus près des gens qui travaillent de façon scientifique (quoique je ne le fasse certainement pas moi-même) que de mes confrères artistes.» [1, p.71] Malgré ses fréquentes et vigoureuses dénégations de toute compréhension mathématique ou d'organisation scientifique de son travail, Escher possédait une profonde curiosité mathématique, une ténacité et, enfin, une compréhension d'une grande partie du savoir mathématique. L'un des sujets de la recherche d'Escher est aujourd'hui nommé "symétrie de couleurs". C'est seulement récemment, plus de quarante ans après ses investigations, que ce champ commença à recevoir une attention sérieuse de la part des mathématiciens et des autres scientifiques.

Escher était un mathématicien clandestin. II ne possédait aucune référence formelle en mathématiques et, en fait, il semblait aussi mystifié que n'importe quel profane par les textes abracadabrants d'explications de mathématiciens. Mais sa passion avouée pour la production de pavés en formes de créatures s'imbriquant pour 
"At first I had no idea at all of the possibility of systematically building up my figures. I did not know any 'ground rules' and tried, almost without knowing what I was doing, to fit together congruent shapes that / attempted to give the form of animals. Gradually, designing new motifs became easier as a result of my study of the literature on the subject, as far as this was possible for someone untrained in mathematics, and especially as a result of my putting forward my own layman's theory, which forced me to think through the possibilities. It remains an extremely absorbing activity, a real mania to which I have become addicted, and from which I sometimes find it hard to tear myself away." [1, p.164]

The very fact that Escher considered himself not a mathematician allowed him to pursue his investigations in his own way, unhampered by advice and criticism from "experts". He suggests in another paragraph from Regelmatige vlakverdeling the professionals' narrowness of view:

"In mathematical quarters, the regular division of the plane has been considered theoretically, since it forms part of crystallography. Does this mean that it is an exclusively mathematical question? In my opinion, it does not. Crystallographers have put forward a definition of the idea, they have ascertained which and how many systems or ways there are of dividing a plane in a regular manner. In doing so, they have opened the gate leading to an extensive domain, but they have not entered this domain themselves. By their very nature they are more interested in the way in which the gate is opened than in the garden lying behind it." $[1, p .156]$

What Escher did, he did for himself, for his own understanding and use, not for publication or explanation to scientists. His questions were not theirs, nor was his mode of inquiry. He was sparked from within to create tilings of the plane. remplir le plan le conduit à l'exploration systématique des possibilités et des contraintes de tels pavés et de tels pavages, et aussi de la question liée au coloriage de ceux-ci. Il y fait al lusion dans un paragraphe de son livre Regelmatige vlakverdeling (Division régulière du plan) publié en 1958 :

"Au début, je n'avais aucune idée de la possibilité de construire mes figures de façon systématique. Je ne connaissais aucune règle de base et j'essayais, la plupart du temps sans comprendre ce que je faisais, d'ajuster des formes congruentes auxquelles je tentais de donner l'allure d'animaux. Peu à peu, la création de nouveaux motifs devint plus simple grâce à mon étude de la littérature sur le sujet, autant que cela était possible pour quelqu'un qui n'avait pas de formation mathématique, et particulièrement grâce à la mise sur pied de ma propre théorie de profane, ce qui m'a forcé à réfléchir à l'ensemble des possibilités. Cela demeure une activité extrêmement absorbante, une véritable manie à laquelle je m'adonne et de laquelle j'ai parfois de la difficulté à m'arracher.» [1, p.164]

C'est le fait qu'Escher ne se considérait pas lui-même mathématicien qui lui permit de poursuivre à sa manière ses investigations, libre des avis et des critiques des "experts ". Dans un autre paragraphe de Regelmatige vlakverdeling, il évoque l'étroitesse d'esprit des professionnels :

"Dans les quartiers mathématiques, la division régulière du plan a été considérée de façon théorique, puiqu'elle fait partie de la cristallographie. Cela signifie-t-il que ce soit une question exclusivement mathématique? Selon moi, ce n'est pas le cas. Les cristallographes ont proposé une définition du concept, ils ont établi la nature et le nombre des systèmes ou des façons de diviser le plan de manière régulière. En faisant cela, ils ont levé la barrière qui s'ouvrait sur un vaste domaine, mais ils n'ont pas investi euxmêmes ce domaine. Selon leur nature, ils sont plus intéressés par 
In the beginning (1926-27) he achieved only very modest success, and in frustration, sought out sources for study. In 1936 he visited the Alhambra in Granada, Spain, as well as the mosque, La Mezquita, at Córdoba, and made careful colored drawings of the geometric tilings he found there. Also, during this period, his brother B.G. Escher, a geologist at the University of Leiden, brought to his attention the paper by Pólya [8], which he carefully copied in its entirety. Pólya's paper was important to Escher not because of its words (Pólya discussed the plane symmetry groups, a concept which Escher never mentions), but because of the tilings it displayed, illustrating each of the seventeen plane symmetry groups. Escher's understanding was an intuitive, visual understanding - from the illustrations he clearly grasped the role that isometries play in the creation of periodic tilings. His reliance on illustration alone is further evidenced in his study of the 1924 paper by F. Haag [5]. Escher's workbook carefully records the author, title, journal, and pages, but then all that is copied from the paper are Haag's illustrations of tilings by quadrilaterals, pentagons, and hexagons.

After absorbing the visual information in these sources, Escher set out to mold his own theory of the creation, characterization and classification of periodic tilings. His goal was to create interlocking tilings by "creature" tiles, colored so that each tile was clearly visible and not bordered by another tile of the same color (that is, the tiling must be "map colored") and using a minimum number of colors. He wanted to know how to create tiles, in what different ways tiles could be interlocked with adjacent congruent tiles, and how they could be colored according to his constraints. As his study progressed, the coloring question led him to explore how tilings requiring only two colors were related to tilings requiring three colors, and also how to choose colorings compatible with the symmetries of the tiling. Escher's investigations were guided by the goal of a tangible end result. His tilings would be rendered, either as a block print, a fragment of a graphic work or produced la façon d'ouvrir la barrière que par le jardin qui se trouve derrière elle.» $[1, p .156]$

Ce qu'Escher fit, il le fit pour lui-même, pour sa compréhension et son utilisation personnelles, non pas pour publication ni explication aux scientifiques. Ses questions ne sont pas les leurs, non plus que son mode de recherche. Sa création de pavages du plan lui était inspirée de l'intérieur.

Au début (1926-27), il n'atteignit qu'un succès très modéré, et par déception, il rechercha les sources d'étude. En 1936, il visita I'Alhambra à Grenade, en Espagne, de même que la mosquée La Mezquita, à Córdoba; il réalisa soigneusement des dessins coloriés des pavages géométriques qu'il y trouva. Aussi, pendant cette période, son frère B.G. Escher, un géologue de l'Université de Leiden, lui signala l'article de Pólya [8] qu'il recopia avec soin intégralement. L'article de Pólya fut important pour Escher non pas à cause de ses mots (Pólya présentait les groupes de symétrie du plan, un concept qu'Escher n'a jamais mentionné), mais à cause des pavages qui y apparaissaient, illustrant chacun des dixsept groupes de symétrie du plan. La compréhension d'Escher était de type intuitive et visuelle - il saisit clairement, à partir des illustrations, le rôle que jouent les isométries dans la création de pavages périodiques. Sa confiance dans les seules illustrations est encore plus évidente dans son étude de 1924 de l'article de F. Haag [5]. Escher note soigneusement dans son cahier d'exercices l'auteur, le titre, la revue et les pages, mais il ne copie de cet article que les illustrations qu'Haag avait fait de pavages réalisés à l'aide de quadrilatères, de pentagones et d'hexagones.

Après avoir absorbé l'information visuelle de ces sources, Escher se proposa de modeler sa propre théorie de la création, de la caractérisation et de la classification des pavages périodiques. Son but était de créer des pavages imbriqués constitués de pavés en forme de "créatures" coloriés de telle sorte que chaque pavé 
as ceramic tiles for a wall mural or cylindrical column. Thus the practical aspect of production influenced his theory of classification.

The fact that Escher undertook a systematic study of these many aspects of tiling, rather than be satisfied with a few interesting original examples, may seem out of character. Yet this was not so strange. He once wrote in a letter, "My affinity with the exact approach to natural phenomena is probably related to the milieu in which I grew up as a boy: my father and three of my brothers were all trained in the exact sciences or engineering, and I have always had an enormous respect for these things." $[6, p .30]$

As he sought to understand how to create tiles, Escher invented his own symbolic notation to describe how portions of the edges of a tile related to each other and to edges of adjacent tiles. Although some of his symbols are those used by mathematicians, Escher gave them new meaning. The sketches in Figures 1 and 2 are copied from an early workbook, and illustrate his notation. The notation, although unconventional, is excellent - it is succinct and symbolically suggestive of the isometries which relate edge pieces of tiles.

In this early workbook, we see Escher methodically considering sorting, labeling and relabeling the various possibilities for periodic tilings by a single asymmetric tile, using translations, glidereflections, 2- and 4-fold rotations. He used other symbolic notation which visually suggests how tiles are related to adjacent tiles: 2-fold rotation centers were marked with small circles and 4fold centers with small squares. In addition, each tile in a tiling was given an asymmetric mark (usually a "hook"), and the positioning of these marks clearly identifies which isometry carries a given tile into an adjacent tile. (See Figures 1 and 2.) The use of all of the symbolic notation renders additional explanation unnecessary and indeed, Escher gives very few words of explanation in his soit clairement visible et non adjacent avec aucun pavé de la même couleur (le pavage doit être colorié à la façon d'une carte géographique), eten utilisant un nombre minimal de couleurs. Il cherchait à savoir comment créer des pavés, de combien de façons différentes les pavés pouvaient s'imbriquer et comment ils pouvaient être coloriés de façon à respecter ses contraintes. Comme son étude progressait, la question du coloriage le mena à explorer les liens entre les pavages ne requérant que deux couleurs et ceux en requérant trois, ainsi que le choix de coloriages compatibles avec les symétries du pavage. Les recherches d'Escher étaient orientées dans le but d'obtenir un résultat final tangible. Ses pavages devaient être traduits sous forme de gravure, comme partie d'une oeuvre graphique ou produites en tuiles de céram ique pour une murale ou pour une colonne cylindrique. Ainsi, l'aspect pratique de production a influencé sa théorie de classification.

Le fait qu'Escher entreprit une étude systématique de ces nombreux aspects du pavage, plutôt que de se satisfaire de quelques exemples originaux intéressants, peut sembler surprenant. Mais ce n'était pas si étrange. Il a déjà écrit dans une lettre: "Mon affinité avec une approche exacte des phénomènes naturels est probablement reliée au milieu qui m'a vu grandir : mon père et trois de mes frères ont été formés en sciences exactes ou en génie et j'ai toujours eu un énorme respect pour ces choses. » [6, p.30]

Pendant qu'il essayait de comprendre la mécanique de création des pavés, Escher inventa sa propre notation symbolique pour décrire comment les parties des arêtes d'un pavé sont liées entre elles et aux arêtes des pavés adjacents. Même si certains de ses symboles sont ceux utilisés par les mathématiciens, Escher leur a donné une nouvelle signification. Les esquisses des figures 1 et 2 sont copiées de l'un de ses premiers cahiers de travail ; ils illustrent sa notation. La notation, même si elle n'est pas conventionnelle, est excellente - elle est concise et elle suggère symboliquement les isométries qui relient les parties d'arêtes des pavés. 
notes. The interplay of Escher's "pure research" with his artistic goal of highly recognizable interlocked creatures is shown by his frequent emphatic self-reminder that appears next to the schematic and symbolic representations of tilings: "voorbeeld maken!" (make an example!).

In the years 1936-41, Escher produced forty-three colored periodic drawings which cover a wide variety of symmetry types. His research gave him mastery of the geometric constraints and so liberated his witty artistic genius. Over the course of his lifetime, he produced over one hundred fifty such periodic drawings; more than forty of these are reproduced in [7]. In 1941-42 he set down a final version of his investigations in a notebook, and used his classification scheme to categorize each of his creature tilings.

His notebook begins with a schematic chart (Figure 3) which gives a complete visual description of each of twenty-four types of tiling, including lattice type (A: parallelogram, B: rhombus, C: rectangle, $D$ : square, $E$ : isosceles right triangle), location of rotation centers, relation of tiles to adjacent tiles by isometries, and coloring of tiles. Combining the visual information, we can characterize for each type which isometries preserve and which reverse color.

Taking Escher's advice, we will illustrate the content of his symbolism with an example. His chart shows for type IXD a square lattice with two 4-fold centers of rotation (diametrically opposite) and two 2-fold centers of rotation (diametrically opposite) at the corners of each square. The 4-fold rotations reverse the colors of the tiles and the 2-fold rotations preserve them (Figure 4a). Escher's drawing no.13 of dragonflies (Figure $\mathbf{4 b}$ ) bears his classification IXD*. The underlying square lattice can be seen in the drawing; indeed, the edges of each dragonfly "tile" meet at the four corners of a square. We can observe that the 2- and 4-fold rotations which carry a given dragonfly into a neighboring one are located at these corners, and the 4-fold rotations carry each dark
Dans ce cahier de travail de la première heure, on voit Escher examiner méthodiquement, trier, étiqueter et réétiqueter les nombreuses possibilités de pavages périodiques basés sur un seul pavé asymétrique, en utilisant les translations, les réflexions glissées et les rotations d'ordre 2 et 4 . II utilisa une autre notation symbolique ; elle suggère visuellement les relations entre pavés adjacents : les centres de rotation d'ordre 2 sont indiqués par de petits cercles et les centres d'ordre 4 par de petits carrés. De plus, chaque pavé est doté d'une marque asymétrique (habituellement un "crochet") et l'emplacement de ces marques identifie clairement l'isométrie qui transporte un pavé donné sur un pavé adjacent. (Voir les figures 1 et 2.) L'utilisation de toute la notation symbolique rend inutile toute explication additionnelle - et en fait, Escher donne peu de mots d'explication dans ses notes. L'interaction de la "recherche pure» d'Escher et de ses visées artistiques de création d'êtres imbriqués grandement reconnaissables est montrée par ses fréquentes notes de rappel apparaissant en marge des représentations schématiques et symboliques de pavages : "voorbeeld maken!" (faire un exemple!).

Dans les années 1936-41, Escher produisit quarante-trois dessins périodiques coloriés couvrant une large variété de types de symétrie. Ses recherches lui donnèrent une maîtrise des contraintes géométriques et libérèrent ainsi l'esprit de son génie artistique. Tout au long de sa vie, il produisit plus de cent cinquante dessins périodiques de cette sorte ; plus de quarante de ceux-ci sont reproduits dans [7]. En 1941-42, il mit par écrit une version finale de ses recherches dans un cahier de notes, et il utilisa son procédé de classification afin de catégoriser chacun de ses pavages de créatures.

Son cahier de notes débute sur un diagramme schématique (figure 3) qui donne une description visuelle complète de chacun des vingt-quatre types de pavage, y compris le type de réseau ( $A$ parallélogramme, $B$ : losange, $C$ : rectangle, $D:$ carré, $E$ : triangle 


\section{FIGURE $1 \doteq$}

Escher's symbolic notation succinctly describes how edges of tiles are related. The first three lines (starting with the top line) are interpreted as follows: $A B$ half-turns into $B G ; A B$ glidereflects into $C D ; A B$ translates into $\mathrm{EF}$.

\section{FIGURE 3}

Escher's overview chart which classifies 24 different types of

2-colored tilings.
La notation symbolique d'Escher décrit de façon concise la relation entre les arêtes des pavés. Les trois premières lignes (en commencant par la plus haute) s'interprètent comme suit: $A B$ se transporte sur $B G$ par un demi-tour $A B$ se transporte sur $C D$ par une réflexion glissée; AB se transporte sur EF par une translation.

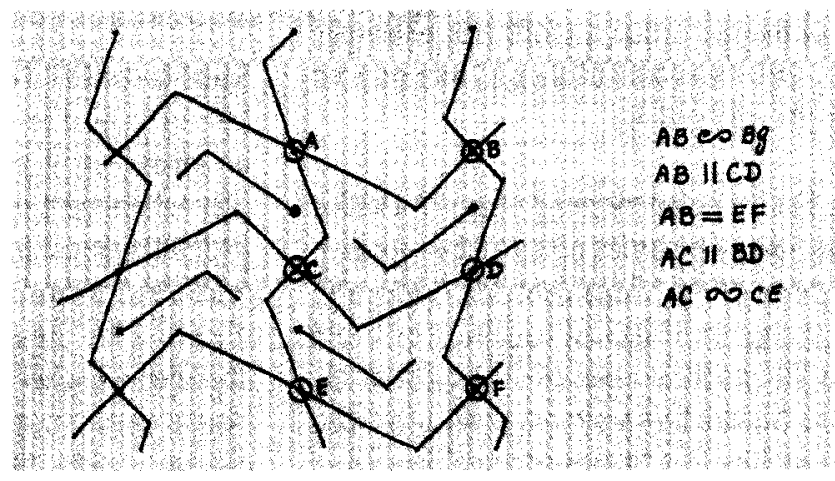

FIGURE 2 יווי

More of Escher's notation. The top line reads: $A B$ half-turns into $B C$ which quarter turns into $B E$.

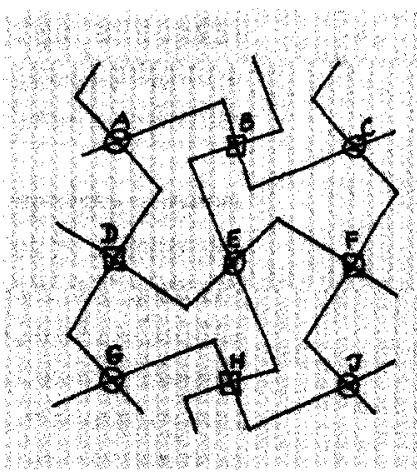

Encore la notation d'Escher. La ligne supérieure se lit: $A B$ se

transporte sur $B C$ par un demitour et $B C$ se transporte sur $B E$ par un quart de tour.
Le tableau résumé d'Escher qui classifie 24 types différents de pavages 2-coloriés.

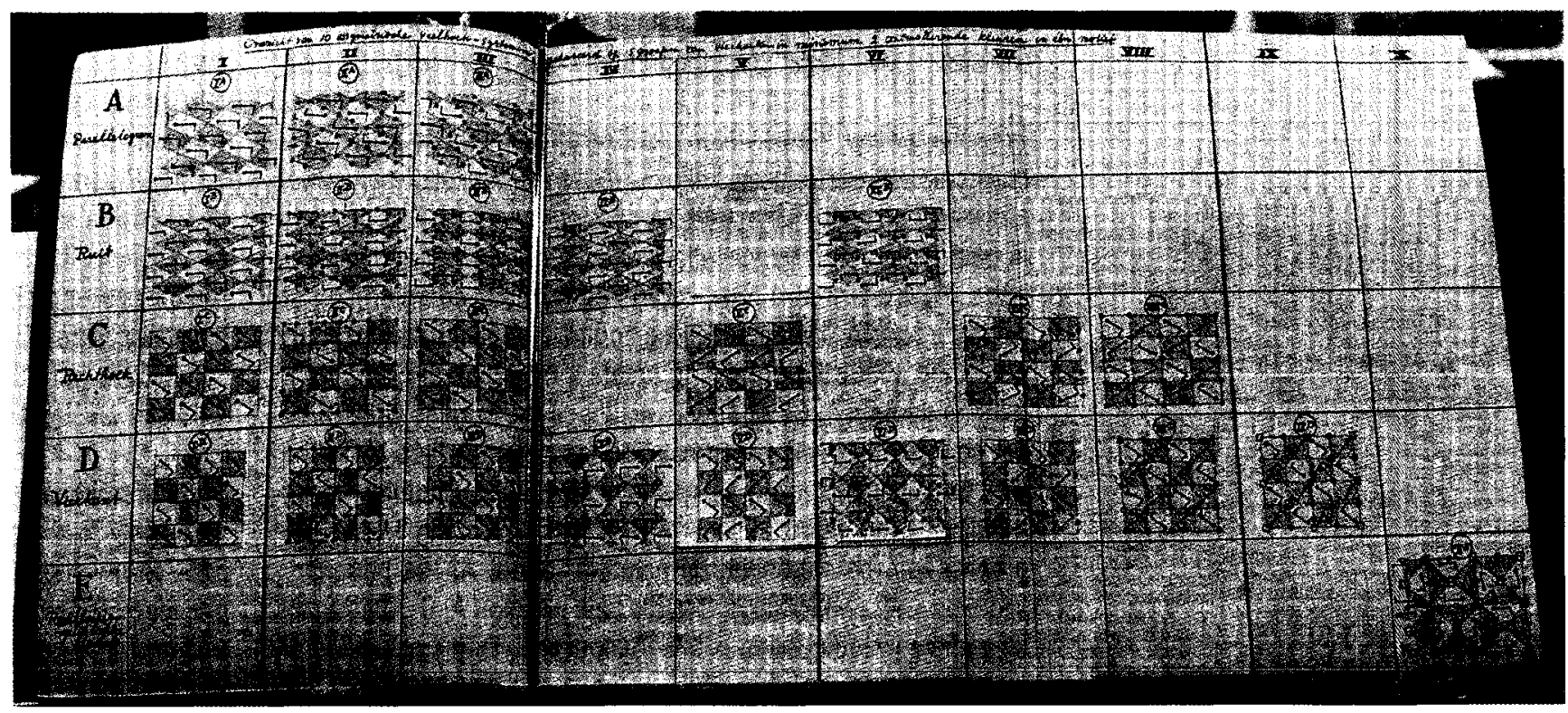

TMPNI NAIF STRIISTIIRAI F NO
ABNO BCL BE. $A B=g H$

AO LOE OOEH AD O Dg L DE COEF $A D=C F$

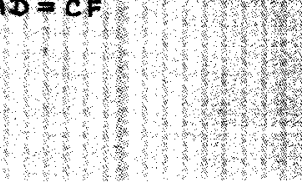


(blue) dragonfly into a white one and vice-versa, while the 2-fold rotations carry each dragonfly into one of the same color. The * in the classification symbol of this drawing indicates that the motif (dragonfly) has reflection symmetry. In his classification system, Escher did not allow reflections to carry tiles into adjacent tiles; however he made note of the fact when a motif was bilaterally symmetric (using the "), and often (but not always) this induced reflection symmetry into the whole tiling.

Unlike crystallographers, Escher noted the exact shape of a lattice tile, whether or not all possible symmetries of that shape occur in the tiling. For example, many of his tilings have his $D$ (square) lattice classification even though the tiling may have no 2- or 4-fold rotation symmetry. Here the practical (execution) aspect of his considerations is apparent. Square tiles are most easily produced by standard tile works. In addition, his "lattice polygon" in each of the five categories $A, B, C, D, E$, corresponds to a single tile (what mathematicians call a fundamental domain), rather than to a translation unit (what crystallographers call a unit cell).

In Escher's view, tilings which required three colors (in order to be map-colored) were closely linked to those which were 2-colorable, and were derived by a dynamic process of transition. This process is best understood by viewing Escher's own schematic explanation. Figure 5 shows how, beginning with a 2-colored tiling of Escher's type IA, a segment of the boundary (with endpoints $A, B$ ) is pivoted about the point $A$ to create a new boundary segment (with endpoints $A, C$ ), and then all tiles of the original (top) tiling are so altered (using the translation isometries which carry the tiles into adjacent tiles) to create a new tiling (middle) which requires three colors. Escher labels this new tiling IA-IA. The process can be continued by pivoting (about $A$ ) the boundary segment with endpoints $A, C$ to the new position $A, D$. Altering all tiles of the (middle) tiling in this manner results in a new tiling of type IA (bottom) which can be 2-colored. Escher carefully applies rectangle isocèle), l'emplacement des centres de rotation, la relation entre des pavés adjacents par des isométries, et le coloriage des pavés. En combinant l'information visuelle, on peut, pour chaque pavé, identifier les isométries qui laissent invariantes les couleurs et celles qui les inversent.

Selon le conseil d'Escher, on illustrera le contenu de son symbolisme à l'aide d'un exemple. Son tableau indique pour le type IXD un réseau carré possédant deux centres de rotation d'ordre 4 (diamétralement opposés) et deux centres de rotation d'ordre 2 (diamétralement opposés) situés aux coins de chaque carré. Les rotations d'ordre 4 inversent les couleurs des pavés et les rotations d'ordre 2 les préservent (figure 4a). Le dessin numéro 13 des libellules d'Escher (figure 4b) est classifié IXD*. On peut voir le réseau carré sous-jacent dans le dessin; en fait, les arêtes de chaque "pavé" libellule se rencontrent aux quatres coins d'un carré. On peut observer que les rotations d'ordre 2 et d'ordre 4 qui transportent une libellule donnée sur une voisine sont situées en ces coins et que les rotations d'ordre 4 transportent chaque libellule foncée (bleue) sur une blanche et vice-versa, tandis que les rotations d'ordre 2 transportent chaque libellule sur une libellule de la même couleur. L'étoile ( ${ }^{*}$ ) dans le symbole de classification de ce dessin indique que le motif (libellule) possède une symétrie de réflexion. Dans son système de classification, Escher n'admettait pas les réflexions pour transporter les pavés sur des pavés adjacents; il notait toutefois la présence d'un motif bilatéralement symétrique (en utilisant *) et, souvent, (mais pas toujours) ceci induisait une symétrie de réflexion dans le pavage entier.

Contrairement aux cristallographes, Escher notait la forme exacte d'un pavé de réseau, même si toutes les symétries possibles de cette forme n'apparaissaient pas dans le pavage. Par exemple, plusieurs de ses pavages ont sa classification de réseau $D$ (carré) même si le pavage ne possède pas de symétrie de rotation d'ordre 2 ou d'ordre 4. Ici, l'aspect pratique (l'exécution) de ses considé- 


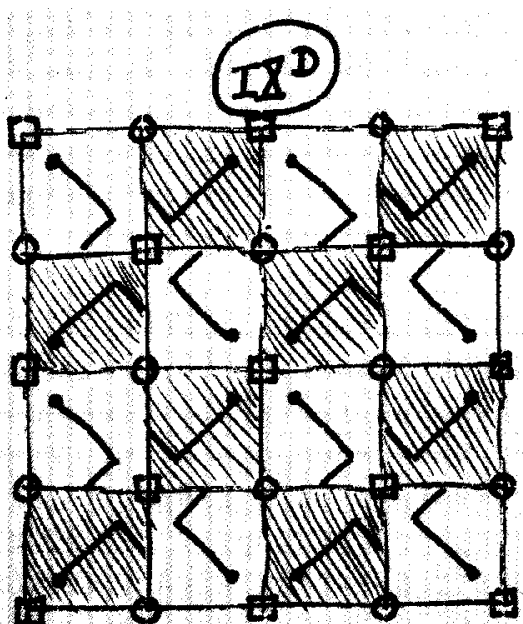

FIGURE $4 a$. Il.

Escher's type IXD from the chart in Figure 3

Le type IXD d'Escher issu du tableau de la figure 3.

Escher's drawing no. 13 of dragonflies (winter 1937-38) is classified as type $\mid X D^{\star}$

Le dessin d'Escher numéro 13 des libellules (hiver 193738) est classifié de type IXD*.

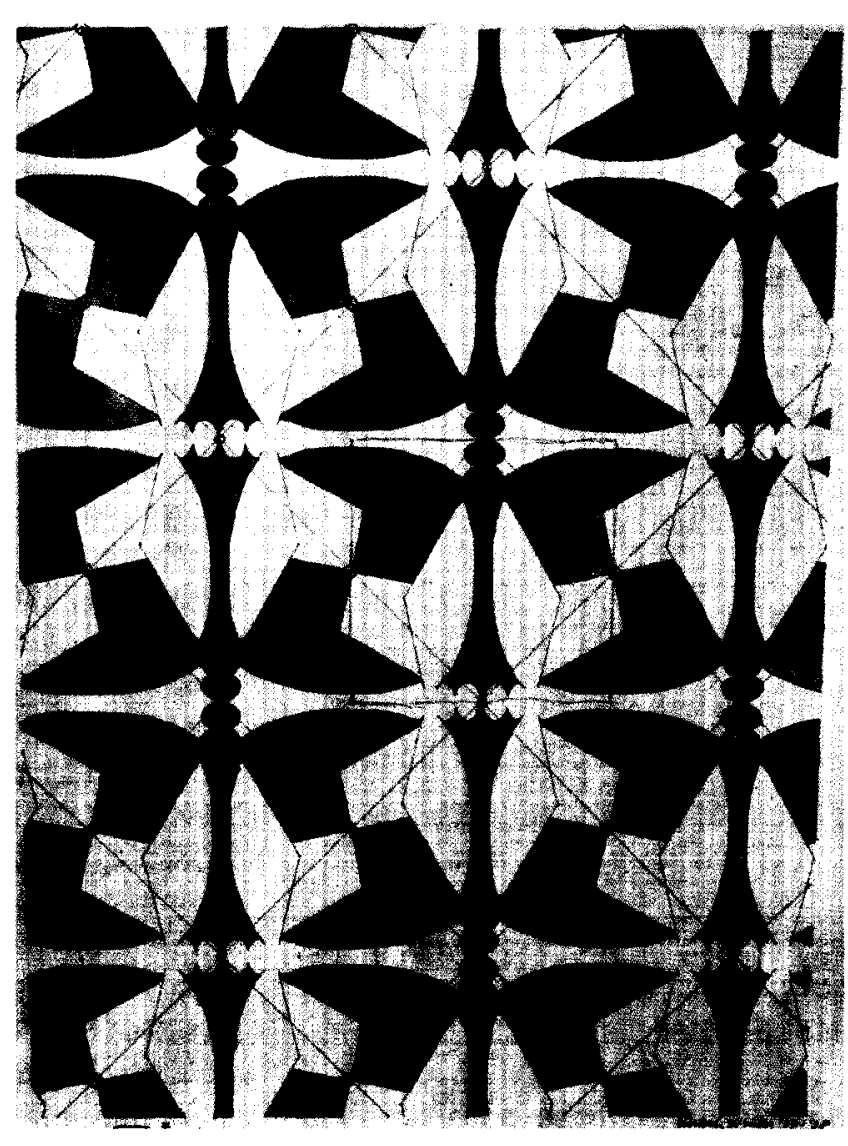

3)
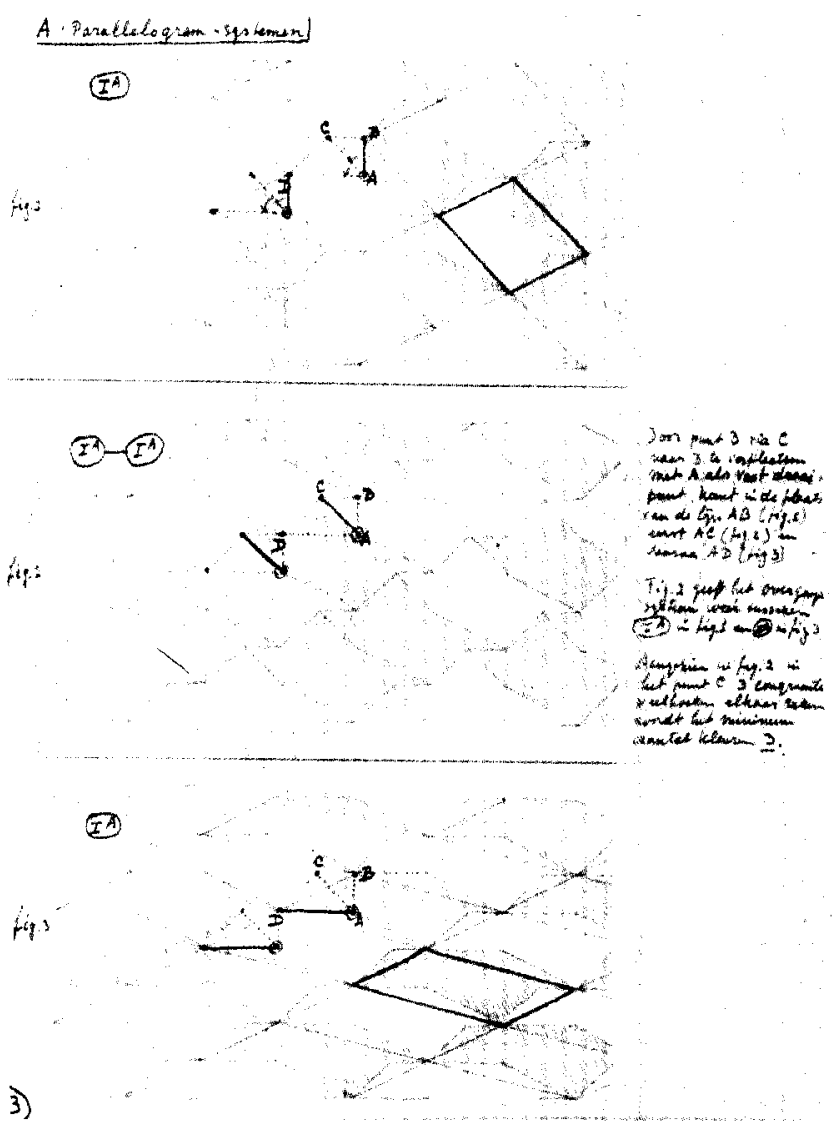

FIGURE 5 . .ll.

Escher's notebook page describing the process of transition from a type IA tiling to IA-IA to a new IA tiling.

Une page du cahier de notes d'Escher décrivant le processus de transition d'un pavage de type IA à un de type IA-IA, vers un nouveau pavage de type IA. 


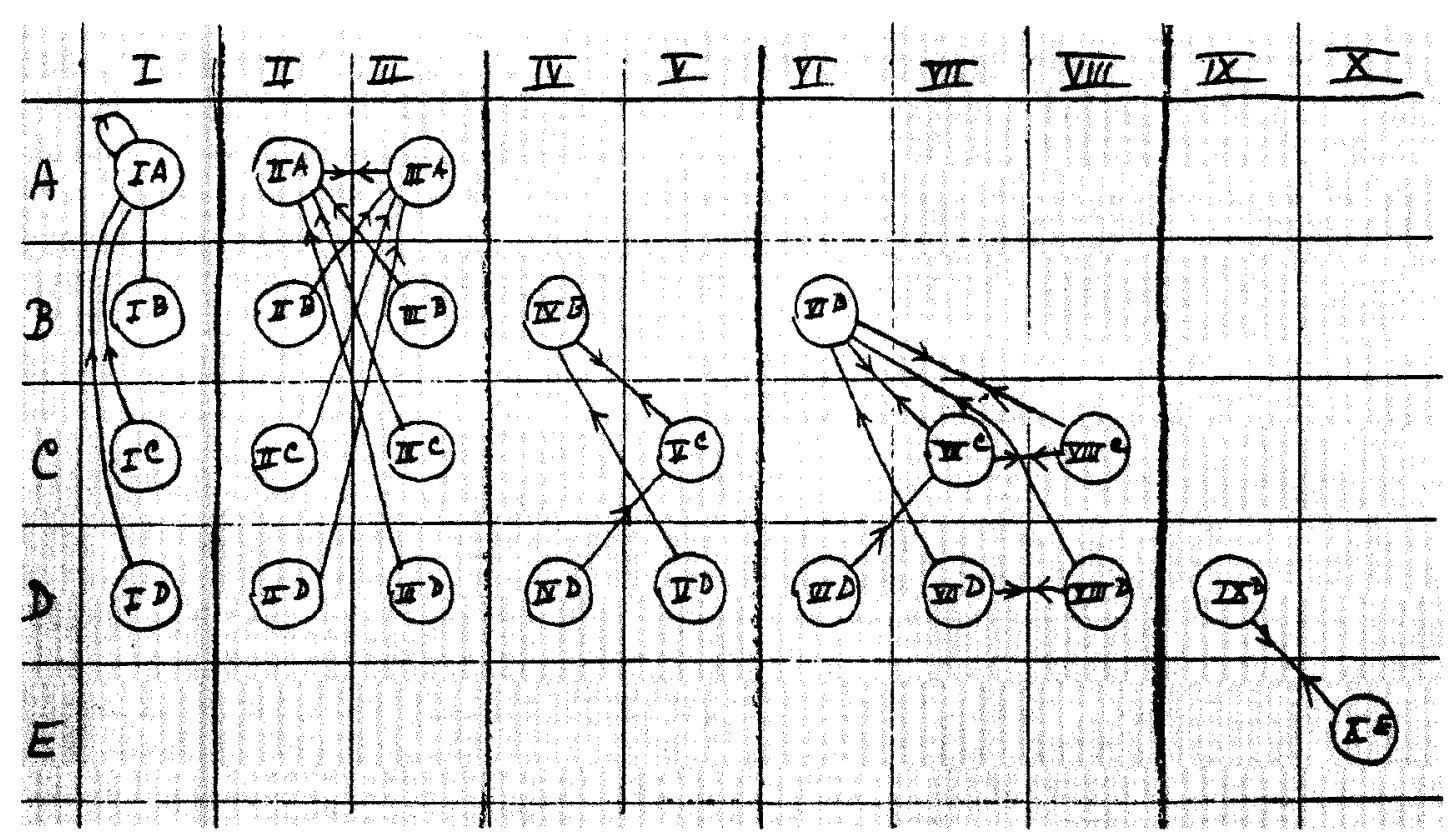

FIRURE 6

Escher's diagraph showing which of his types were related by the transition process.

\section{Le graphe orienté} d'Escher montrant quels sont les types liés par le processus de transition. this process to all of his two-colorable tilings (in Figure 3), exploring the many variations possible, and the possible linkages of 2-color types using the twice-applied process described above.

His notebook shows a summary (a directed graph!) of these linkages of "Escher types" using the transition process, with five clearly separated categories (Figure 6). These categories are, in fact, the five different plane symmetry groups p1, p2, pg, pgg and p4. Thus, although he did not use the crystallographer's notation of symmetry groups, he made a fundamental discovery: the transition process changed the shape of the tiles (often even changing the isohedral type of a tiling), and changed the number of colors required, but did not change the symmetry group of the tiling. rations est apparent. Il est plus facile de produire des pavés carrés à l'aide des travaux standards sur les pavés. De plus, son "polygone de réseau» dans chacune des cinq catégories A, B, C, $D, E$, correspond à un simple pavé (ce que les mathématiciens appellent un domaine fondamental), au lieu d'une unité de translation (que les cristallographes appellent une cellule unité).

Selon Escher, les pavages qui requièrent trois couleurs (pour être coloriés comme une carte) sont intimement liés à ceux qui sont 2-coloriables, et sont dérivés par un processus dynamique de transition. On comprend mieux ce processus en regardant les propres explications schématiques d'Escher. La figure 5 montre, en débutant avec un pavage 2-colorié du type IA selon Escher, comment un segment de la frontière (d'extrémités $A, B$ ) est pivoté autour du point $A$ pour créer un nouveau segment de frontière (d'extrémités $A, C$ ) ; tous les pavés du pavage original (en haut) sont alors modifiés (en utilisant les isométries de translation qui transportent les pavés sur des pavés adjacents) pour créer un nouveau pavage (au milieu) qui requiert trois couleurs. Escher étiquette ce nouveau pavage IA-IA. On peut continuer le processus en faisant pivoter (autour de $A$ ) le segment de frontière d'extrémités $A$ et $C$ en une nouvelle position $A, D$. Une telle modification de tous les pavés du pavage (du milieu) résulte en un nouveau pavage de type IA (en bas) qui peut être 2-coloriable. Escher appliqua soigneusement ce processus à tous ses pavages 2-coloriables (figure 3), explorant les nombreuses variations possibles et les possibles liens entre les pavages 2-coloriables par une double application du processus décrit plus haut.

On trouve dans son cahier de notes un résumé (un graphe orienté!) de ces liens de «types Escher» obtenus par le processus de transition, classés en cinq catégories clairement séparées (figure 6). Ces catégories sont, en fait, les cinq différents groupes de symétries planes p1, p2, pg, pgg et p4. Ainsi, même s'il n'utilisait pas la notation des cristallographes pour les groupes de symétries, il 
Map-coloring a tiling is fairly easy to achieve, and can be done in a variety of ways. However, from the beginning, Escher seems to have linked the process of coloring a tiling with the process of symmetry operations. Inevitably this led to "perfect" colorings, that is, colorings in which all symmetries of the uncolored tiling are compatible with the coloring. What this means is that if a tiling of congruent tiles has some tiles colored red and others colored white, then every symmetry that sends one red tile to a white tile must send every red tile to a white tile. In other words, each symmetry of the uncolored tiling must induce a permutation on the set of colors of the tiling. The idea of having the symmetries of a tiling "drive" the colors was not considered by mathematicians and crystallographers until the 1950's.

Escher was fascinated with the concept of duality (Day and Night, Sky and Water, Heaven and Hell, ...), and his use of two contrasting colors or two interlocked motifs served to emphasize such duality. His notebook includes a chapter specifically investigating the creation of tilings by two different motifs. Beginning with a tiling by a single tile shape (and requiring either two or three colors), he split the tile into two distinct (differently shaped) tiles and then used the symmetries of the tiling to split all of the tiles in the same way. He was mainly interested in creating tilings by two motifs which could be colored in just two colors, giving further emphasis to the implied duality. Thus some of his tilings of this type consist of two motifs, with all copies of one motif colored the same color and all copies of the other motif a single contrasting color (so that either motif can play the role of figure while the other is the ground). But other tilings created by the splitting process show two motifs, in which some copies of each motif are one color, and other copies of each motif are a contrasting color (however, the coloring of these tilings is always "perfect", compatible with the symmetries of the tiling). For a few of his types, he notes distinct ways in which the tiles can be split. Figure 7 shows one of his two schematic illustrations of this process applied to his fit une découverte fondamentale : le processus de transition modifiait la forme des pavés (modifiant même souvent le type isoèdre d'un pavage), modifiait le nombre de cou leurs requises, mais ne modifiait pas le groupe de symétrie du pavage.

Le coloriage cartographique d'un pavage est relativement facile à réaliser, et on peut le faire de différentes façons. Toutefois, depuis le début, Escher semble avoir lié le processus de coloriage d'un pavage et le processus des opérations de symétrie. Inévitablement, ceci mena à des coloriages "parfaits", c'est-à-dire des coloriages pour lesquels toutes les symétries du pavage non colorié sont compatibles avec le coloriage. Ceci signifie que si un pavage de pavés congruents possède des pavés de couleur rouge et d'autres de couleur blanche, alors toute symétrie qui envoie un pavé rouge sur un pavé blanc doit envoyer tout pavé rouge sur un pavé blanc. En d'autres termes, chaque symétrie du pavage non colorié doit induire une permutation sur l'ensemble des couleurs du pavage. L'idée que les symétries d'un pavage puissent "entraîner» les couleurs ne fut pas considérée par les mathématiciens et les cristallographes avant les années cinquante.

Escher était fasciné par le concept de dualité (Jour et nuit, Le ciel et l'eau, Le paradis et l'enfer, ... ) et son utilisation de deux couleurs contrastantes ou de deux motifs imbriqués servaità accentuer une telle dualité. Son cahier de notes inclut un chapitre sur la recherche spécifique de pavages créés à l'aide de deux motifs différents. Débutant avec un pavage constitué d'une seule forme de pavé (et requérant deux ou trois couleurs), il divise le pavé en deux pavés distincts (de formes différentes) et utilise les symétries du pavage afin de diviser tous les pavés de la même façon. II était principalement intéressé par la création de pavages sur deux motifs qui pourraient être coloriés en seulement deux couleurs, donnant encore plus d'emphase à la dualité implicite. Ainsi, certains de ses pavages de ce type consistent en deux motifs où toutes les copies d'un motif sont coloriées de la même couleur et toutes les copies 
type IA; variant 2 shown is the second of two types of splittings. Figure 8 shows a finished rendering of a tiling of this type, the embossed cover of his 1958 book Regelmatige vlakverdeling. Only in the last few years have such tilings been the subject of mathematical investigation (they are termed 2-isohedral tilings by Grünbaum and Shephard [4]).

Escher devotes the last section of his notebook to a very compact description of the perfectly colored tilings based on what he terms a "triangle system". These are the tilings which have 3-fold or 6fold rotation centers. He notes that three colors are almost always necessary for such tilings, and invents a notation which records for a given tiling the following information: triangle system, number of distinct motifs, 3-fold (only) or 6-fold rotations, number of colors. Some of his most successful colored tilings (of lizards and of butterflies, for example) show his mastery of these types.

Many who have admired Escher's work may have suspected he possessed far more mathematical talent and understanding than he was willing to profess. The evidence of Escher's private research is overwhelming. He was a (secret) mathematician. de l'autre motif sont coloriées d'une seule autre couleur contrastante (de telle sorte que n'importe quel motif peut jouer le rôle de figure tandis que l'autre joue le rôle de fond). Mais d'autres pavages créés à l'aide du procédé de division montrent deux motifs pour lesquels certaines copies de chaque motif sont d'une couleur et d'autres copies de chaque motif sont d'une couleur contrastante (toutefois, le coloriage de ces pavages est toujours "parfait», compatible avec les symétries du pavage). Pour quelques uns de ses types, il note différentes façons de diviser les pavés. La figure 7 montre l'une de ses deux illustrations schématiques de ce procédé appliqué à son type IA; la variante 2 est le deuxième de deux types de division. La figure 8 montre le produit final d'un pavage de ce type, la couverture en relief de son livre de 1958, Regelmatige vlakverdeling. C'est seulement dans les quelques dernières années que de tels pavages devinrent l'objet de recherches mathématiques (Grünbaum et Shephard [4] les appellent pavages 2-isoèdres).

Escher consacre la dernière section de son cahier de notes à une description très concise des pavages parfaitement coloriés basés sur ce qu'il appelle un «système de triangles". Ce sont les pavages qui possèdent des centres de rotation d'ordre 3 ou d'ordre 6 . II note que de tels pavages nécessitent presque toujours trois couleurs et il inventa une notation qui tient compte pour un pavage donné de l'information suivante: le système de triangles, le nombre de motifs distincts, les rotations d'ordre 3 (seulement) ou d'ordre 6 , le nombre de couleurs. Quelques uns de ses pavages coloriés les plus connus (les lézards et les papillons, par exemple) montrent sa maitrise de ces types.

Plusieurs de ceux qui ont admiré les travaux d'Escher ont pu soupçonner qu'il possédait beaucoup plus de talent et de compréhension mathématiques qu'il était prêt à l'admettre. L'évidence de la recherche privée d'Escher est saisissante. II était un mathématicien (clandestin). 


\section{FIGURE 7}

The splitting of a type IA tiling into a tiling by two motifs (tiles),

each motif always col-

ored the same color

(Escher's variant 2).

La division d'un

pavage de type IA en

un pavage de deux

motifs (pavés)

chaque motif étant

toujours colorié de la

même couleur (la

variante 2 d'Escher).

\section{FIGURE 8}

Escher's design for

the cover of

Regelmatige

vlakverdeling.
Le dessin d'Escher

pour la couverture de

Rege/matige

vlakverdeling.

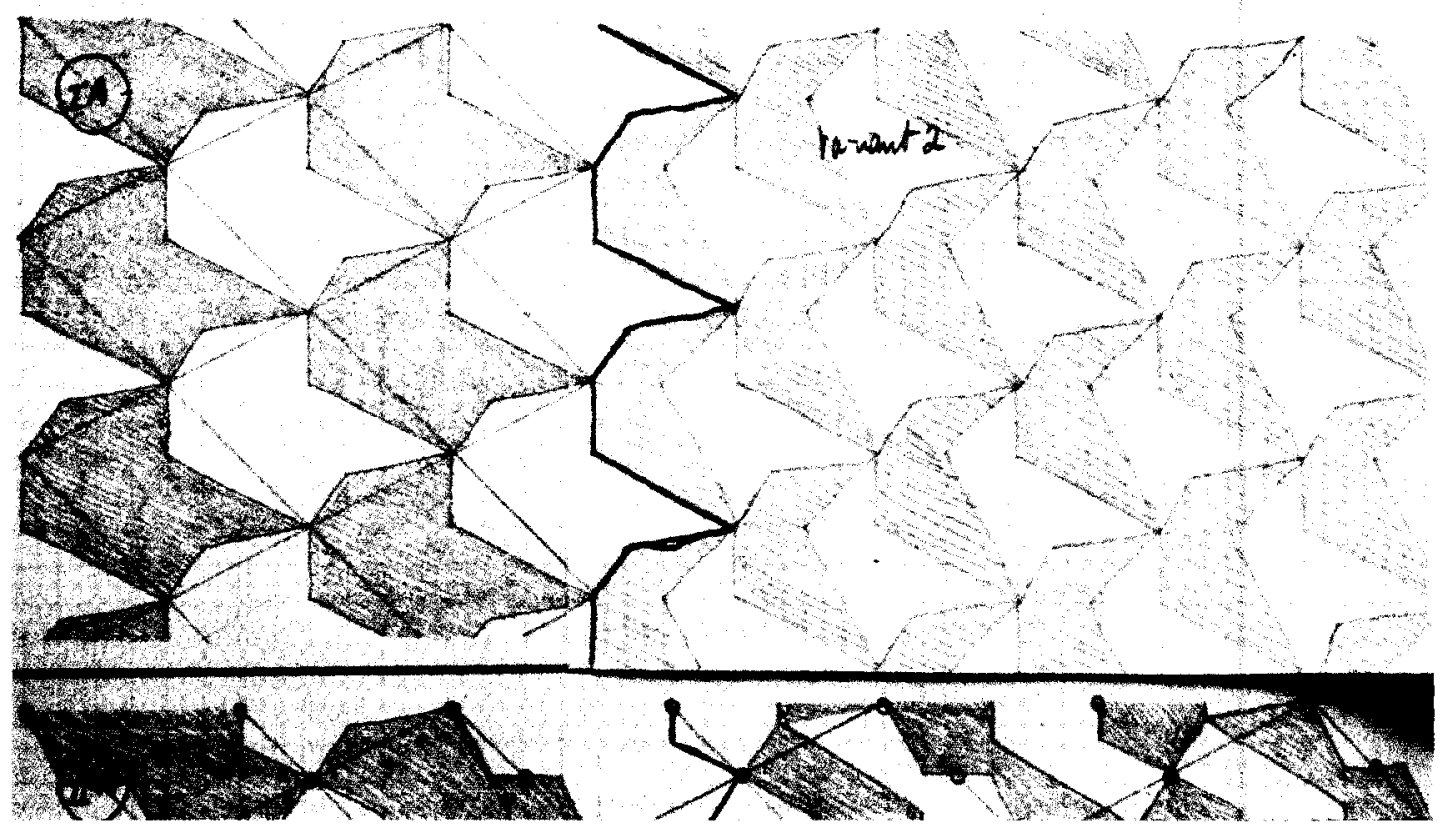

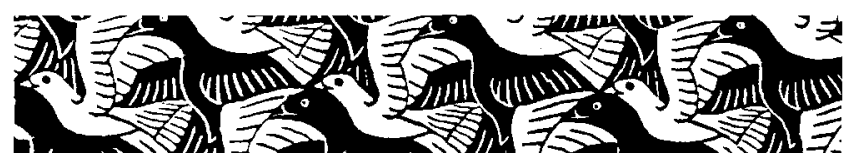

Q

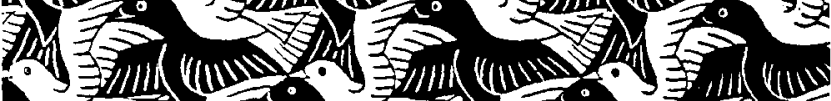

1 年

(4)1111.

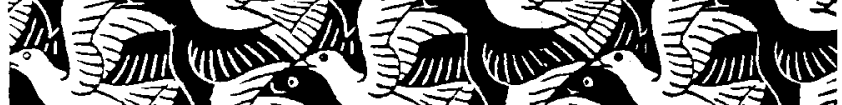

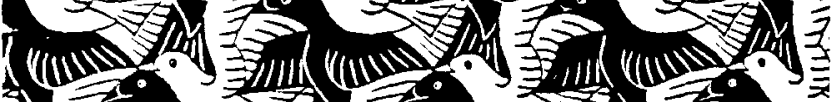

染)

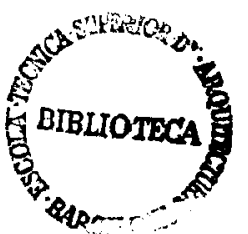

TOPOLOGIE STRUCTURALE NN 15 
This article is based on a talk given in July 1986 at the Eugene Strens Memorial Conference on Intuitive and Recreational Mathematics held at the University of Calgary. Partial funding for the research was received from the Faculty Development and Research Committee of Moravian College.

I wish to express my thanks to the Escher Foundation and the Haags Gemeentemuseum for the privilege of examining the Escher notebooks and periodic drawings in 1976.

. Illi.
Cet article est basé sur un exposé donné en juillet 1986 à la conférence Eugene Strens Memorial sur les mathématiques intuitives et récréatives qui eut lieu à l'Université de Calgary. Le Faculty Development and Research Committee du Moravian College a subventionné en partie la recherche.

Je tiens à exprimer mes remerciements à la Fondation Escher et au Haags Gemeentemuseum pour le privilège qu'il m'ont accordé en 1976 d'examiner les cahiers de notes d'Escher et ses dessins périodiques.

ollu.

\section{REFERENCES / RÉFERENCES}

\section{[1] F.H. Bool, J.R. Kist, J.L. Locher and} F. Wierda

M.C. Escher, His Life and Complete

Graphic Work.

Harry N. Abrams, New York, 1982

\section{[2] M.C. Escher}

The authentic collection of all Escher drawings from the Gemeentemuseum The Hague on microfische, Inter Documentation Company AG, Zug, 1980

[3] M.C. Escher

Regelmatige vlakverdeling.

De Roos, 1958. Translated and reprinted

in [1] above, pp. 155-173.

[4] B. Grünbaum and G.C. Shephard

Tilings and Patterns.

W.F. Freeman \& Co., New York, 1987

\section{[5] F. Haag \\ Die regelmässigen Planteilungen un \\ Punksysteme" \\ 2. Kristall, 58 (1923) 478-488.}

[6] J.L. Locher, ed.

The World of M.C. Escher.

Harry N. Abrams, New York, 1972.

[7] C.H. MacGillavn

Symmetry Aspects of M.C. Escher's

Periodic Drawings.

Oosthoek, Utrecht, 1965; reprinted as

Fantasy and Symmetry, The Periodic

Drawings of M.C. Escher, Harry N.

Abrams, New York, 1976

\section{[8] G. Pólya}

Über die Analogie der

Kristallsymmetrie in der Ebene"

Z. Kristall., 60 (1924) 278-282.
[9] D. Schattschneider
"In Black and White: How to Create
Perfectly Colored Symmetric Patterns"

Comp. \& Math with Appl., 12B 3/4 (1986) 673-695

[10] D. Schattschneider tor his Colored Periodic Drawings". In M.C. Escher: Art and Science, Nort Holland, 1986, p. 82-96.

[11] R.L.E. Schwarzenberger

"Colour Symmetry".

Bull. London Math. Soc. 16 (1984) $209-240$

[12] M. Senecha

"Point Groups and Color Symmetry".

Z. Kristall., 142 (1975) 1-23.
[13] M. Senechal

"Color Groups".

Discrete Appl. Math., 1 (1979) 51-73.

[14] T.W. Wieting

The Mathematical Theory of Chromatic

Plane Ornaments.

Marcel Dekker, New York, 1982 